\title{
Chemical Constituents, Cytotoxic, Antioxidant and Cholinesterases Inhibitory Activities of Silene Compacta (Fischer) Extracts
}

\author{
Mehmet Boğa
}

\begin{abstract}
In Turkey, Silene species have been used as infusion in urinary bladder and biliary tract diseases in traditional medicine. Silene species have been also consumed as food in Anatolia and Europe. In this study, the phenolic, fatty acid and essential oil profiles and the cytotoxic, antioxidant and cholinesterases inhibitory activities, and total phenolic-flavonoid content of Silene compacta Fischer (SC) were studied. The essential oil and fatty acid compositions of $S$. compacta were determined by using GC/MS in the current study. The chemical composition of the methanol extract was determined using LC-MS/MS for quantitative and qualitative
\end{abstract}

purposes. The major components of the essential oil and fatty acid were identified as $\alpha$-selinene (12.4\%) and palmitic acid (26.3\%), respectively. The methanol extract (SCM: S. compacta methanol extract) which possessed the best activity in four tested antioxidant methods among the tested extracts exhibited very strong cholinesterases inhibitory activities. Additionaly, this extract indicated the highest cytotoxic effect against A549 cells. In the SCM extract, hesperidin and rutin, quinic and malic acids were quantified by LC-MS/MS as major contituents.

Keywords: Silene compacta, LC-MS/MS, fatty acid, essential oil, anticholinesterase, antioxidant, cytotoxicity.
Mehmet Boğa

Department of Pharmaceutical Technology, Faculty of Pharmacy, Dicle University, 21280 Diyarbakir, Turkey

Corresponding Author:

Mehmet Boğa

e-mail:mehmetboga1980@gmail.com,mehmet.boga@dicle.edu.tr

Submitted / Gönderilme: 29.12.2016

Revised / Düzeltme: 19.01 .2017

\section{INTRODUCTION}

The genus Silene L. (Caryophyllaceae) is represented by 150 taxa in Turkey, 67 of them are endemic [1]. Silene species are known in Anatolia as "Nakıl çiçeği", "Gıvışganotu", "Gı1 gıcı", "Salkım çiçeği” [2]. Their roots and aerial parts have been used as infusion in urinary bladder and biliary tract diseases. Silene vulgaris (Moench) have been also consumed as food in Anatolia and Europe [2, 3].

Silene species possess mainly triterpene saponins and ecdysteroids [4, 5]. Ecdysteroids have been found in more than 120 species and subspecies of Silene from 155 species so far tested [6]. The steroid-containing fractions of some Silene species are immunosuppressive, potentially antiinflammatory [6], inhibit the proliferation of cancer cells by inducing apoptosis [5], and show in vivo anticancer activity in mice [7]. On the other hand, several studies are devoted to the fatty acid and essential oil composition of various Silene species [8-10].

Depending on the life expectancy and the aging of the world's population, various health problems gain importance both socially and economically. Nowadays, the most beneficial results in the treatment of Alzheimer's disease, taken as a 
single drug group is indicated by acetylcholinesterase (AChE) inhibitors. However, only this group of drugs is used in the mild treatment to moderate Alzheimer's disease and side effects required make identify new anti-Alzheimer's drugs. With the prolonging human life, the increase of chronic diseases (cancer, cardiovascular disease, Alzheimer's, and so on) has attracted the interest to the antioxidants nowadays $[11,12]$. On the other hand, synthetic antioxidants are used to extend the shelf life of foods and prevent their degradation. Synthetic antioxidants, BHA (butylated hydroxyanisole), BHT (butylated hydroxytoluene), PG (propyl gallate) and TBHQ (t-butyryllhydroquinone), and by-products formed from them can lead to various diseases [13]. For this reason, finding new antioxidant substances in replace of synthetic ones have gained importance in this field. The antioxidants may be also relevant in slowing the progression of Alzheimer's disease which is frequently seen among elderly people all around the world. Consequently, consumers have been more interested in natural antioxidants to protect their health [14]. Additionaly, recent several scientific studies have been focused on the phenolic compounds of the plants having a number of pharmacological effects and the biological activities [15].

A literature survey showed that there are no reports on the fatty acid, essential oil, phenolic profiles, cytotoxic, antioxidant and anticholinesterase activities of $S$. compacta. At the beginning, the essential oil and fatty acid compositions of $S$. compacta were determined by using GC/MS in the current study. In the next step, related cytotoxic, antioxidant and cholinesterases inhibitory activities; total phenolicflavonoid contents were examined. Finally, the chemical composition of the methanol extract was determined using LC-MS/MS for quantitative and qualitative purposes.

\section{MATERIALS AND METHODS}

\section{Plant material}

The aerial parts of Silene compacta FISCHER were collected from northwestern Turkey (Şile-Istanbul) in August 2012 by Dr. A. Ertaş, and identified by Dr. Yeter Yeşil. A voucher specimen was deposited in the Herbarium of Istanbul University (ISTE 98051).

\section{Extraction of essential oil and GC/MS conditions steam distillation}

Essential oils were obtained using a Clevenger apparatus from the aerial parts of plant, which were crumbled into small pieces and soaked in distilled water for $3 \mathrm{~h}$. The obtained essential oils were dried over anhydrous $\mathrm{Na}_{2} \mathrm{SO}_{4}$ and stored at $+4{ }^{\circ} \mathrm{C}$ for a sufficient period of time. The essential oil were diluted using $\mathrm{CH}_{2} \mathrm{Cl}_{2}(1: 3 \mathrm{v} / \mathrm{v})$ prior to GC/FID and GC/ MS analysis. The GC/MS and GC/FID procedure described by Ertas et al. [15] were applied. GC/FID performed using Thermo Electron Trace GC FID detector and GC/MS performed using same GC and Thermo Electron DSQ quadrupole for MS.

\section{Preparation of extracts for biological activities and GC-MS}

Powdered the aerial parts of $S$. compacta were weighed (100 g) and sequentially macerated three times with petroleum ether $(250 \mathrm{~mL})$, acetone $(250 \mathrm{~mL})$, methanol $(250 \mathrm{~mL})$ and water $(250 \mathrm{~mL})$ at $25^{\circ} \mathrm{C}$ for $24 \mathrm{~h}$. After filtration, the solvent was evaporated to get the crude extracts. This yielded $0.89 \%$ petroleum ether extract, $1.1 \%$ acetone extract, $5.8 \%$ methanol extract, and 3.4\% water extract $(\mathrm{w} / \mathrm{w})$. The petroleum ether extract was analyzed to determine its fatty acid composition by GC/MS.

\section{GC/MS conditions and esterification of fatty acid}

Esterification of the petroleum ether extract and GC/MS procedure described by Ertas et al. [16] were applied. Thermo Scientific Polaris Q GC-MS/MS was used.

\section{Preparation of methanol extract for LC-MS/MS}

The air-dried and powdered plant materials $(10 \mathrm{~g})$ were extracted three times with $100 \mathrm{~mL}$ of methanol for $24 \mathrm{~h}$ at room temperature. The solvent was removed from the filtered extract under vacuum at $30^{\circ} \mathrm{C}$ in a rotary evaporator. Methanol extract was diluted to $250 \mathrm{mg} / \mathrm{L}$ and fitrated with $0.2 \mu \mathrm{m}$ microfiber filter prior to LC MS/MS analysis.

\section{Method validation parameters for LC-MS/MS}

In this study, twenty-four phenolic compounds (flavonoids, flavonoid glycosides, phenolic acids, phenolic aldehyde, coumarin) and three non-phenolic organic acids were qualified and quantified in S. compacta. Rectilinear regression equations and the linearity ranges of the studied standard compounds were given in Table 1. Correlation coefficients were found to be higher than 0.99 . The limit of detection (LOD) and limit of quantitation (LOQ) of the reported analytical method were shown in Table 1. For the 
studied compounds, LOD ranged from 0.05 to $25.8 \mu \mathrm{g} / \mathrm{L}$ and LOQ ranged from 0.17 to $85.9 \mu / \mathrm{L}$ (Table 1). Moreover, the recoveries of the phenolic compounds ranged from $96.9 \%$ to $106.2 \%[12,16]$.

\section{Determination of total phenolic and flavonoid contents}

Total phenolic and flavonoid contents which were expressed as pyrocatechol and quercetin equivalents, respectively, were determined as reported in the literature $[17,18]$. The following equations were used to calculate total phenolic and flavonoid contents of the extracts:

Absorbance $=0.0128$ pyrocatechol $(\mu \mathrm{g})+0.0324\left(\mathrm{R}^{2}=0.9924\right)$

Absorbance $=0.1701$ quercetin $(\mu \mathrm{g})-0.0778\left(\mathrm{R}^{2}=0.9939\right)$

\section{Antioxidant activity of the extracts}

$\beta$-Carotene-linoleic acid test system [19], DPPH free radical scavenging activity [20], ABTS cation radical decolorisation [21] and cupric reducing antioxidant capacity (CUPRAC) [22] assays were carried out to determine the antioxidant activity.

\section{Cholinesterases inhibitory activities of the extracts}

A spectrophotometric method developed by Ellman et al. [23] was used to indicate the acetyl- and butyryl-cholinesterase inhibitory activities.

\section{Cytotoxic activity}

\section{Cell culture}

A549 and L929 fibroblast cells which were stored in liquid nitrogen tank were centrifuged after dissolution. Later, these cells were placed on a 96-well plate after addition of $3 \mathrm{~mL}$ (DMEM 10\% + fetalbov serum 100\%+ containing 1\% antibiotics), and incubated under $5 \% \mathrm{CO}_{2}$ and at $37^{\circ} \mathrm{C}$. When the cells reached sufficient growth, they were discharged with trypsin-EDTA solution, and passaging process was continued.

\section{Determination of cytotoxicity by MTT assay}

The MTT assay was performed in accordance with ISO 10993-5 standards. This method is sensitive for cell proliferation measurement that 3-[4,5-dimethylthiazol-2yl]-2,5-diphenyltetrazolium bromide (MTT) tetrazolium salt is used. MTT is reduced to insoluble formazan dye in water by mitochondrial enzymes associated with metabolic activity. MTT reduction is primarily associated with the glycolytic activity in the cells and depends on the presence of $\mathrm{NADH}$ (nicotin amide adenine dinucleotide) and NADPH (nicotinamide adenine dinucleotide phosphate). In the reactions of mitochondria of healty cells or early stages of apoptotic cells, colored formazan crystals constitute with the degredation of the tetrazolium ring which is found in MTT solution by dehydrogenase enzymes in cell mitochondria. The color change which observed in living cells gives the absorbance values in Elisa reader.

L929 fibroblast and A549 cells was cultivated on 96-well plate $\left(10 \times 10^{3}\right.$ cells/well). Cells were incubated for $24 \mathrm{~h}$. Later, previously prepared plant extracts at different concentrations $(0-12.5 \mu \mathrm{g} / \mathrm{mL}-25 \mu \mathrm{g} / \mathrm{mL}-50 \mu \mathrm{g} / \mathrm{mL}-100 \mu \mathrm{g} / \mathrm{mL})$ was applied onto the cells and then incubated for $24 \mathrm{~h}$. The samples were studied 5 times. As a positive control, the medium was only applied onto cells. After $24 \mathrm{~h}$, waste in each well were discarded and $100 \mu \mathrm{L}$ of medium and $20 \mu \mathrm{L}$ of MTT solution were added. After $3.5 \mathrm{~h}$ incubation at $37^{\circ} \mathrm{C}$, $150 \mu \mathrm{L}$ of MTT solvent was added to wells, and cells were incubated for extra 15 minutes. In order to determine cell viability, absorbance values of plates were recorded by ELISA reader at $570 \mathrm{~nm}$. According to the absorbance values of control group, percentage cell viability was calculated.

\section{Statistical analysis}

The total phenolic-flavonoid contents, antioxidant and anticholinesterase activity assays results were shown as means \pm standard deviation. The results were evaluated using an unpaired $t$-test and one way analysis of variance ANOVA. The differences were regarded as statistically significant at $p$ $<0.05$.

\section{RESULTS AND DISCUSSION}

\section{Quantitative analysis of phenolic compounds by LC-MS/ MS}

Several studies are present in literature reporting the use of liquid chromatography electrospray ionization tandem mass spectrometry to perform quantitative analyses of phenolic compounds $[12,14,24]$. Thus, for quantitative purpose, an accurate method on a mass spectrometer equipped with a triple quadrupole analyzer was developed for the analyses of twenty-four phenolic compounds (flavonoids, flavonoid glycosides, phenolic acids, phenolic aldehyde, coumarin) 
and three non-phenolic organic acids in the methanol extract of $S$. compacta methanol extract (SCM). When considered the results of LC-MS/MS in general, rutin (2147.97 \pm 107.35 $\mu \mathrm{g} / \mathrm{g}$ extract) and hesperidin $(1941.64 \pm 95.06 \mu \mathrm{g} / \mathrm{g}$ extract) were found to be the most abundant compounds in the SCM extract (Table 1 and Figure 1).

Furthermore, vanillin $(95.59 \pm 4.65 \mu \mathrm{g} / \mathrm{g}$ extract), hyperoside $(439.40 \pm 21.51 \mu \mathrm{g} / \mathrm{g}$ extract), luteolin $(72.46 \pm 4.12 \mu \mathrm{g} / \mathrm{g}$ extract), kaempferol (34.63 $\pm 2.11 \mu \mathrm{g} / \mathrm{g}$ extract), apigenin $(50.43 \pm 2.65 \mu \mathrm{g} / \mathrm{g}$ extract $)$ and chrysin $(16.74 \pm 0.85 \mu \mathrm{g} / \mathrm{g}$ extract) were also detected in the SCM extract as flavonoid (Table 1 and Figure 1). Additionally, gallic (22.59 \pm 1.13 $\mu \mathrm{g} / \mathrm{g}$ extract), chlorogenic (151.79 $\pm 7.40 \mu \mathrm{g} / \mathrm{g}$ extract), protocatechuic $(178.10 \pm 9.07 \mu \mathrm{g} / \mathrm{g}$ extract), tr-caffeic (only detect), p-coumaric (134.68 $\pm 6.83 \mu \mathrm{g} / \mathrm{g}$ extract), rosmarinic $(152.53 \pm 7.44 \mu \mathrm{g} / \mathrm{g}$ extract $), 4-\mathrm{OH}$ benzoic $(50.68 \pm 2.60 \mu \mathrm{g} / \mathrm{g}$ extract) and salicylic acids (41.16 $\pm 2.05 \mu \mathrm{g} / \mathrm{g}$ extract) were determined in SCM extract as phenolic acids. Also, quinic $(1744.71 \pm 83.71 \mu \mathrm{g} / \mathrm{g}$ extract), malic $(1625.02 \pm 86.12 \mu \mathrm{g} / \mathrm{g}$ extract) and tr-aconitic acids $(462.69 \pm 22.84 \mu \mathrm{g} / \mathrm{g}$ extract) were detected and quantified in SCM extract as nonphenolic acids. According to the results of LC-MS/MS, the existence of the most of these compounds was not reported in Silene species before. Additionaly, the current study is the first report on the phenolic composition of $S$. compacta. In literature, there are few studies about chemical profile of Silene species with HPLC [25].

Table 1: Analytical parameters of LC- MS/MS method; Identification and quantification of compounds in methanol extract of S. compacta (SCM) by LC-MS/MS.

\begin{tabular}{|c|c|c|c|c|c|c|c|c|c|}
\hline $\begin{array}{l}\text { Analyte } \\
\text { no }\end{array}$ & Analytes & $\mathrm{RT}^{\mathrm{a}}$ & $\begin{array}{l}\text { Parent ion } \\
(\mathrm{m} / \mathrm{z})^{\mathrm{b}}\end{array}$ & $\mathrm{R}^{2 \mathrm{c}}$ & RSD ${ }^{\mathrm{d}}$ & $\begin{array}{l}\text { Linearity } \\
\text { Range (mg/L) }\end{array}$ & $\begin{array}{l}\text { LOD/LOQ } \\
(\mu \mathrm{g} / \mathrm{L})^{\mathrm{e}}\end{array}$ & Recovery (\%) & 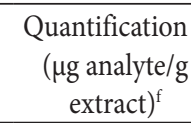 \\
\hline 1 & Quinic acid & 3.36 & 190.95 & 0.9927 & 0.0388 & $250-10000$ & $22.3 / 74.5$ & 103.3 & $1744.71 \pm 83.71$ \\
\hline 2 & Malic acid & 3.60 & 133.05 & 0.9975 & 0.1214 & $250-10000$ & $19.2 / 64.1$ & 101.4 & $1625.02 \pm 86.12$ \\
\hline 3 & tr-Aconitic acid & 4.13 & 172.85 & 0.9933 & 0.3908 & $250-10000$ & $15.6 / 51.9$ & 102.8 & $462.69 \pm 22.84$ \\
\hline 4 & Gallic acid & 4.25 & 169.05 & 0.9901 & 0.4734 & $25-1000$ & $4.8 / 15.9$ & 102.3 & $22.59 \pm 1.13$ \\
\hline 5 & Chlorogenic acid & 5.29 & 353 & 0.9932 & 0.1882 & $250-10000$ & $7.3 / 24.3$ & 99.7 & $151.79 \pm 7.40$ \\
\hline 6 & Protocatechuic acid & 5.51 & 152.95 & 0.9991 & 0.5958 & $100-4000$ & $25.8 / 85.9$ & 100.2 & $178.10 \pm 9.07$ \\
\hline 7 & Tannic acid & 6.30 & 182.95 & 0.9955 & 0.9075 & $100-4000$ & $10.2 / 34.2$ & 97.8 & $39.92 \pm 1.99$ \\
\hline 8 & tr- caffeic acid & 7.11 & 178.95 & 0.9942 & 1.0080 & $25-1000$ & $4.4 / 14.7$ & 98.6 & D. ${ }^{g}$ \\
\hline 9 & Vanillin & 8.57 & 151.05 & 0.9995 & 0.4094 & $250-10000$ & $10.1 / 33.7$ & 99.2 & $95.59 \pm 4.65$ \\
\hline 10 & p-Coumaric acid & 9.17 & 162.95 & 0.9909 & 1.1358 & $100-4000$ & $15.2 / 50.8$ & 98.4 & $134.68 \pm 6.83$ \\
\hline 11 & Rosmarinic acid & 9.19 & 358.9 & 0.9992 & 0.5220 & $250-10000$ & $10.4 / 34.8$ & 101.7 & $152.53 \pm 7.44$ \\
\hline 12 & Rutin & 9.67 & 609.1 & 0.9971 & 0.8146 & $250-10000$ & $17.0 / 56.6$ & 102.2 & $2147.97 \pm 107.35$ \\
\hline 13 & Hesperidin & 9.69 & 611.1 & 0.9973 & 0.1363 & $250-10000$ & $21.6 / 71.9$ & 100.2 & $1941.64 \pm 95.06$ \\
\hline 14 & Hyperoside & 9.96 & 463.1 & 0.9549 & 0.2135 & $100-4000$ & $12.4 / 41.4$ & 98.5 & $439.40 \pm 21.51$ \\
\hline 15 & 4-OH Benzoic acid & 11.38 & 136.95 & 0.9925 & 1.4013 & $25-1000$ & $3.0 / 10.0$ & 106.2 & $50.68 \pm 2.60$ \\
\hline 16 & Salicylic acid & 11.39 & 136.95 & 0.9904 & 0.6619 & $25-1000$ & $4 / 13.3$ & 106.2 & $41.16 \pm 2.05$ \\
\hline 17 & Myricetin & 11.42 & 317 & 0.9991 & 2.8247 & $100-4000$ & $9.9 / 32.9$ & 106.0 & N.D. ${ }^{h}$ \\
\hline 18 & Fisetin & 12.10 & 284.95 & 0.9988 & 2.4262 & $100-4000$ & $10.7 / 35.6$ & 96.9 & N.D. \\
\hline 19 & Coumarin & 12.18 & 146.95 & 0.9924 & 0.4203 & $100-4000$ & $9.1 / 30.4$ & 104.4 & N.D. \\
\hline 20 & Quercetin & 13.93 & 300.9 & 0.9995 & 4.3149 & $25-1000$ & $2.0 / 6.8$ & 98.9 & N.D. \\
\hline 21 & Naringenin & 14.15 & 270.95 & 0.9956 & 2.0200 & $25-1000$ & $2.6 / 8.8$ & 97.0 & N.D. \\
\hline 22 & Hesperetin & 14.80 & 300.95 & 0.9961 & 1.0164 & $25-1000$ & $3.3 / 11.0$ & 102.4 & N.D. \\
\hline 23 & Luteolin & 14.84 & 284.95 & 0.9992 & 3.9487 & $25-1000$ & $5.8 / 19.4$ & 105.4 & $72.46 \pm 4.12$ \\
\hline 24 & Kaempferol & 14.85 & 284.95 & 0.9917 & 0.5885 & $25-1000$ & $2.0 / 6.6$ & 99.1 & $34.63 \pm 2.11$ \\
\hline 25 & Apigenin & 16.73 & 268.95 & 0.9954 & 0.6782 & $25-1000$ & $0.1 / 0.3$ & 98.9 & $50.43 \pm 2.65$ \\
\hline 26 & Rhamnetin & 18.41 & 314.95 & 0.9994 & 2.5678 & $25-1000$ & $0.2 / 0.7$ & 100.8 & N.D. \\
\hline 27 & Chrysin & 20.60 & 253 & 0.9965 & 1.5530 & $25-1000$ & $0.05 / 0.17$ & 102.2 & $16.74 \pm 0.85$ \\
\hline
\end{tabular}

${ }^{a}$ RT: Retention time, ${ }^{b}$ Parent ion $(\mathrm{m} / z)$ : Molecular ions of the standard compounds (mass to charge ratio), ${ }^{\mathrm{c}} \mathrm{R}^{2}$ : coefficient of determination, ${ }^{\mathrm{d}} \mathrm{RSD}$ : relative standard deviation

${ }^{\mathrm{e}} \mathrm{LOD} / \mathrm{LOQ}(\mu \mathrm{g} / \mathrm{L})$ : Limit of deteection/Limit of quantification, ${ }^{\mathrm{f}}$ Values in $\mu \mathrm{g} / \mathrm{g}(\mathrm{w} / \mathrm{w})$ of plant methanol extract, ${ }^{\mathrm{g}} \mathrm{D}$ : peak observed, concentration is lower than the LOQ but higher than the LOD, hN.D: not detected. 


\section{A}

$(\mathrm{x} 10.000)$

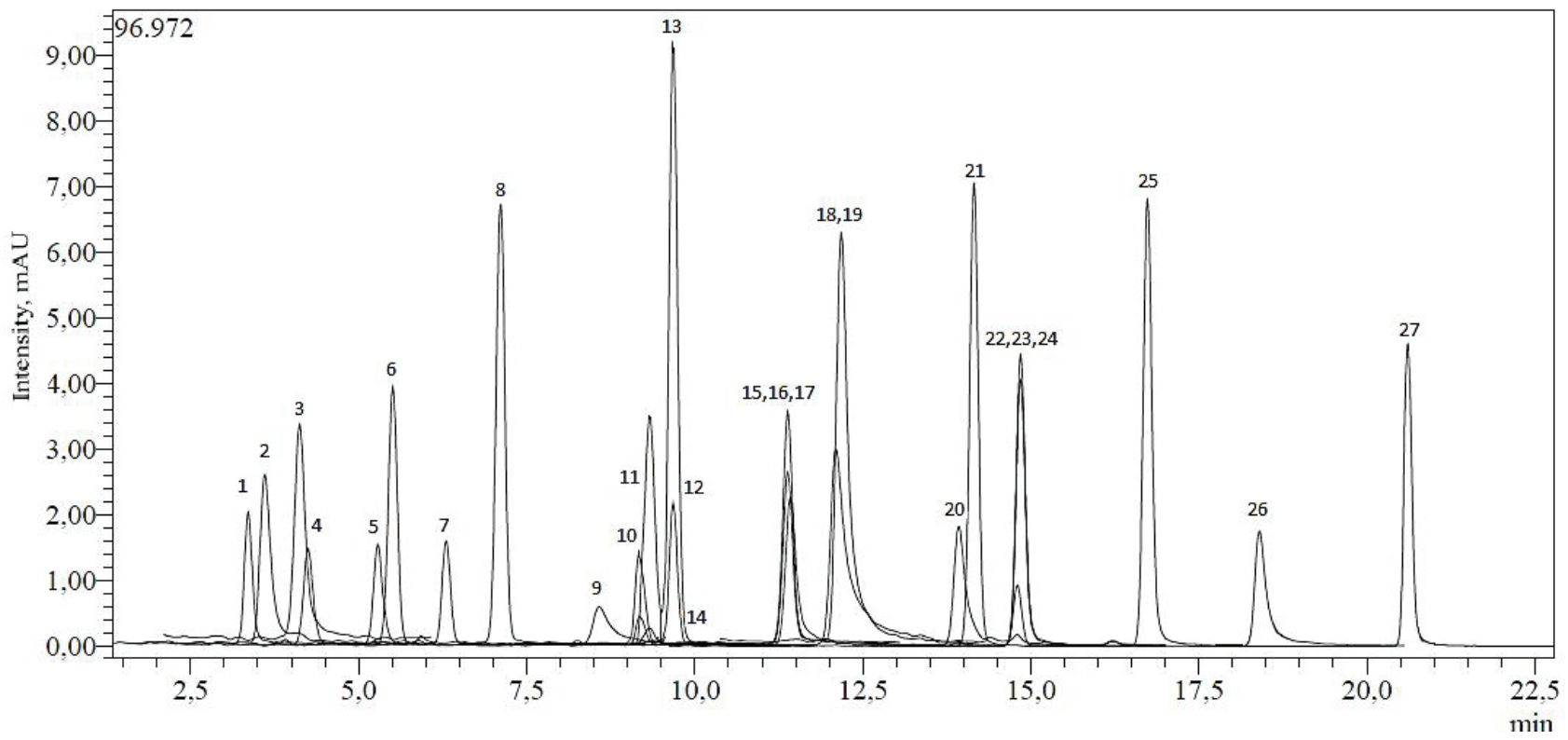

B

\section{$(\mathrm{x} 10.000)$}

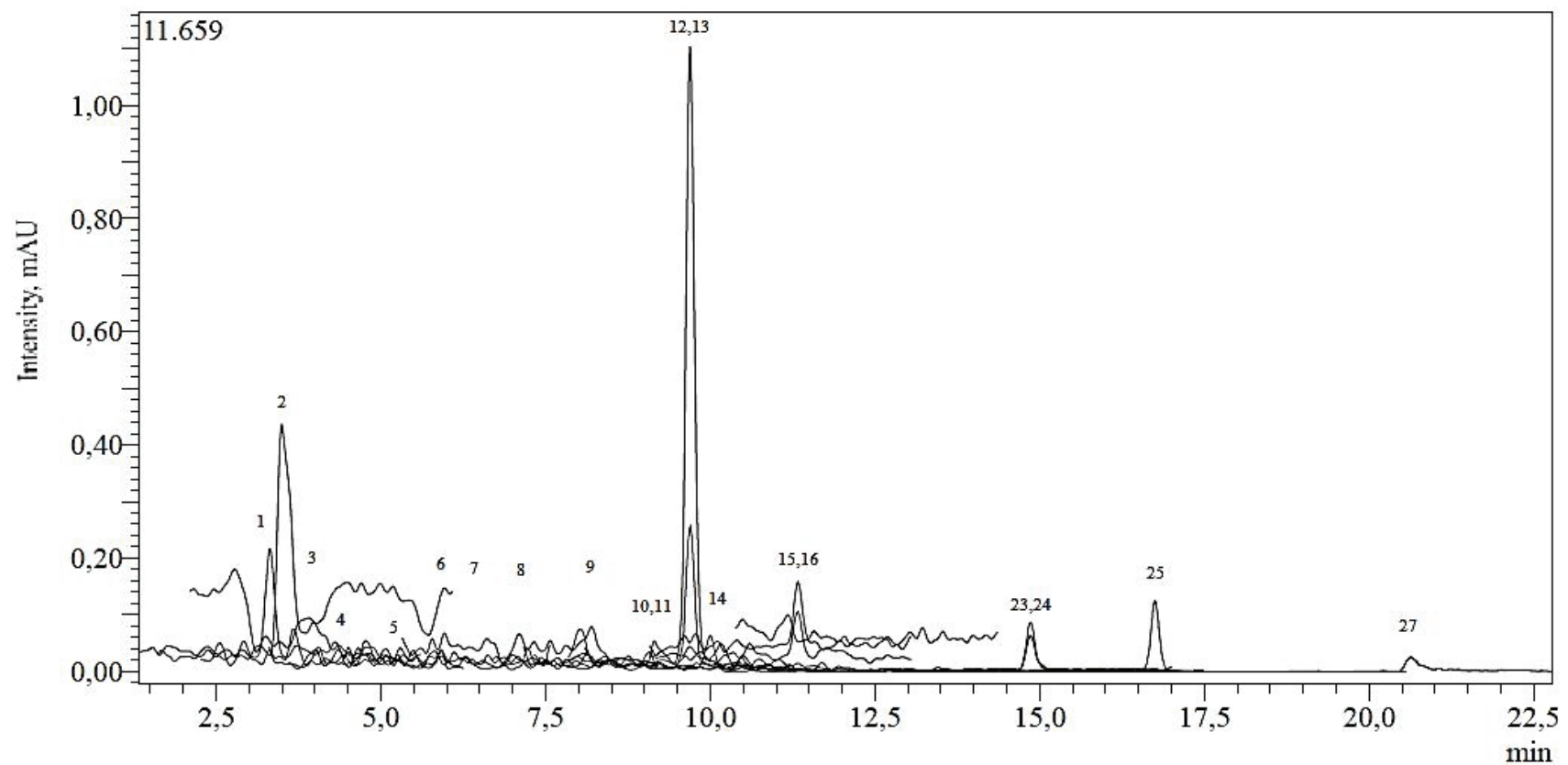

Figure 1. LC-MS/MS chromatograms of A: $250 \mathrm{ppb}$ standard mix, B: S. compacta methanol extract. 1: Quinic acid, 2: Malic acid, 3: tr-Aconitic acid, 4: Gallic acid, 5: Chlorogenic acid, 6: Protocatechuic acid, 7: Tannic acid, 8: tr- caffeic acid, 9: Vanillin, 10: p-Coumaric acid, 11: Rosmarinic acid, 12: Rutin, 13: Hesperidin, 14: Hyperoside, 15: 4-OH Benzoic acid, 16: Salicylic acid, 17: Myricetin, 18: Fisetin,19: Coumarin, 20: Quercetin, 21: Naringenin, 22: Hesperetin, 23: Luteolin, 24: Kaempferol, 25: Apigenin, 26: Rhamnetin, 27: Chrysin. 


\section{Essential oil and fatty acid compositions by GC-MS}

The essential oil of $S$. compacta was determined by GC/ MS analysis. 25 components were identified, constituting $96.1 \%$ of the total oil. The identified compounds are listed in Table 2. According to the results the main constituents of the essential oil were $\alpha$-selinene (12.4\%), Z-8-octadecen-1-ol acetate (10.3\%) and terpinolen (7.7\%).

As far as our literature survey could ascertain, no report is available for the essential oil composition of $S$. compacta. Therefore, this study could be considered the first report on this topic. There are very few studies on essential oil composition of Silene species in the literature. According to a report Vivek et al. the main constituents of the essential oil of S. armeria were 1-butene (39.20\%), methylcyclopropane (21.48\%), 2-butene (17.97\%) and caryophyllene oxide $(7.20 \%)[10]$.
The petroleum ether extract of $S$. compacta were determined by GC/MS analysis for fatty acid composition. As shown in Table 3, 14 components were identified, consitituting 99.30 $\%$ of the petroleum ether extract. According to the results, a large rate in the amounts of palmitic acid (26.3\%), linoleic acid $(17.7 \%)$ and oleic acid (17.1\%) were identified in the extract.

As far as our literature survey could ascertain, no report is available for the fatty acid composition of $S$. compacta. There are few studies on fatty acid composition of Silene species in the literature. According to the report of Kucukboyacı et al. the main constituents of the fatty acid of $S$. vulgaris and S. cserei subsp. aeoniopsis were linoleic acid (65.40\%), oleic acid $(17.80 \%)$ and palmitic acid (8.80\%), respectively [9]. According to the report of Mamadalieva et al. S. barchucia, S. viridiflora and S. wallichiana were determined by GC/

Table 2: Chemical composition of the essential oil from S. compacta.

\begin{tabular}{|c|c|c|c|}
\hline $\mathrm{Rt}(\min )^{\mathrm{a}}$ & Constituents $^{\mathrm{b}}$ & Composition \% & $\mathrm{RI}^{\mathrm{c}}$ \\
\hline 18.98 & Terpinolen & 7.7 & 1086 \\
\hline 24.05 & 1,3-Di-tertbutyl benzene & 3.0 & 1249 \\
\hline 29.38 & Geranyl acetone & 2.4 & 1431 \\
\hline 29.47 & $\beta$-Farnesene & 1.5 & 1447 \\
\hline 30.48 & Valencene & 3.3 & 1484 \\
\hline 30.56 & Germacrene-D & 2.2 & 1485 \\
\hline 30.87 & a-Selinene & 12.4 & 1498 \\
\hline 31.01 & $\beta$-Himachalene & 1.9 & 1505 \\
\hline 31.42 & $\beta$-Cadinene & 3.0 & 1523 \\
\hline 31.83 & a-Amorphene & 1.9 & 1528 \\
\hline 35.52 & 2-Methyl heptadecane & 3.0 & 1746 \\
\hline 36.14 & Pentadecanol & 1.8 & 1778 \\
\hline 36.45 & Octadecane & 2.1 & 1800 \\
\hline 36.74 & 2-Methyl-1-hexadecanol & 1.5 & 1890 \\
\hline 36.87 & 1-Nonadecanol & 4.2 & 2156 \\
\hline 38.22 & Z-14-Octadecen-1-ol acetate & 1.5 & 2185 \\
\hline 38.34 & Z-8-Octadecen-1-ol acetate & 10.3 & 2185 \\
\hline 39.96 & Heneicosane & 4.5 & 2109 \\
\hline 40.13 & 2,5-Di-tert octyl-p-benzoquinone & 7.5 & 2259 \\
\hline 40.61 & Arachidic acid & 5.8 & 2366 \\
\hline 40.87 & Tetracosane & 4.7 & 2407 \\
\hline 43.30 & Heptacosane & 1.8 & 2700 \\
\hline 43.63 & 1-Hexacosanol & 4.0 & 2852 \\
\hline 44.10 & Nonacosane & 2.4 & 2900 \\
\hline \multirow[t]{2}{*}{44.41} & Ethyl iso-allocholate & 1.7 & 3094 \\
\hline & Total & 96.1 & \\
\hline
\end{tabular}

aRetention time (as minutes), ${ }^{\mathrm{b} C}$ Compounds listed in order of elution from a HP-5 MS column. A nonpolar Phenomenex DB-5 fused silica column, ${ }^{\mathrm{R} I}$ Retention indices (DB-5 column). 
Table 3: GC-MS Analysis of the petroleum ether extract of S. compacta.

\begin{tabular}{llc}
\hline Rt $(\min )^{\mathrm{a}}$ & Constituents $^{\mathrm{b}}$ & Composition \% \\
\hline 12.00 & Lauric acid, methyl ester & 1.8 \\
18.60 & Myristic acid, methyl ester & 4.5 \\
24.94 & Palmitoleic acid, methyl ester & 0.2 \\
25.27 & Palmitic acid, methyl ester & 26.3 \\
28.47 & Margaric acid, methyl ester & 1.0 \\
29.75 & Phytol & 1.2 \\
30.64 & Linoleic acid, methyl ester & 17.7 \\
30.77 & Oleic acid, methyl ester & 17.1 \\
30.86 & Linolenic acid, methyl ester & 10.8 \\
31.54 & Stearic acid, methyl ester & 5.1 \\
36.23 & Nonacosanol & 6.1 \\
37.38 & Arachidic acid, methyl ester & 3.2 \\
39.36 & Docosane & 0.7 \\
43.82 & Behenic acid, methyl ester & 3.6 \\
& & 99.3 \\
\hline
\end{tabular}

a Retention time (as minutes), ${ }^{\mathrm{b} C o m p o u n d s ~ l i s t e d ~ i n ~ o r d e r ~ o f ~ e l u t i o n ~ f r o m ~ a ~ H P-5 ~ M S ~ c o l u m n . ~ A ~ n o n p o l a r ~ P h e n o m e n e x ~ D B-5 ~ f u s e d ~ s i l i c a ~ c o-~}$ lumn.

MS analysis for fatty acid composition [8]. According to this report, the main components were determined as linolenic $(25.00,32.80,15.50 \%)$, palmitic acid $(18.50,24.70$, $26.60 \%)$ and linoleic acid $(11.00,18.80,22.50 \%)$, respectively. Consequently, when the results of current study and previous studies in literature were examined together, it could be concluded that the unsaturated fatty acid content of Silene species were higher than their saturated fatty acid content.

\section{Total phenolic-flavonoid contents and antioxidant activity}

Total phenolic and flavonoid contents of the extracts were also determined as pyrocatechol (PEs) and quercetin (QEs) equivalents, respectively (Table 4). The phenolic and flavonoid contents of the methanol (SCM) extract are higher than those of the petroleum ether (SCP), acetone (SCA) and water (SCW) extracts. The total phenolic and flavonoid content of the SCM extract was characterized as the richest among all $(108.94 \pm 2.68 \mu \mathrm{g} / \mathrm{Pes} \mathrm{mg}$ extract and $55.88 \pm 0.15$ $\mu \mathrm{g} /$ Qes mg extract, respectively).

The petroleum ether, acetone, methanol and water extracts prepared from the aerial parts of S. compacta were screened for their possible antioxidant activity by using four complementary methods, namely the amount of $\beta$-carotene bleaching, DPPH free radical scavenging, ABTS cation radical decolorisation assays and Cupric reducing antioxidant capacity assays.

As seen in Table 4, while the SCM extract showed good lipid peroxidation activity $\left(\mathrm{IC}_{50}: 26.37 \pm 0.88 \mu \mathrm{g} / \mathrm{mL}\right)$ in $\beta$-carotene bleaching method, the SCP, SCA and SCW extracts exhibited moderate lipid peroxidation activity $\left(\mathrm{IC}_{50}: 52.45 \pm 1.21,42.91\right.$ \pm 0.72 and $41.94 \pm 1.12 \mu \mathrm{g} / \mathrm{mL}$, respectively). As it can be observed in Table 4, the SCM extract showed good activity $\left(\mathrm{IC}_{50}: 56.78 \pm 2.12 \mu \mathrm{g} / \mathrm{mL}\right)$ in DPPH free radical scavenging method. Besides, the SCP, SCA and SCW extracts showed weak activity in DPPH free radical scavenging method.

As shown in Table 4, the SCP, SCA, SCM and SCW extracts showed the following $\mathrm{IC}_{50}$ values in $\mathrm{ABTS}$ cation radical scavenging assay, $118.18 \pm 2.19,57.78 \pm 1.19,16.91 \pm 0.66$ and $55.45 \pm 2.18 \mu \mathrm{g} / \mathrm{mL}$, respectively. Particularly, the SCM extract indicate strong activity in ABTS cation radical scavenging assay. The SCM extract and a-tocopherol exhibited 1.71 and 1.60 absorbance values in CUPRAC at 100 $\mu \mathrm{g} / \mathrm{mL}$, respectively. The other tested extracts showed weak activity in CUPRAC (Data not shown).

Generally speaking, after examining the antioxidant properties of the four extracts, the SCM extract showed the highest activity among the studied methods. The high antioxidant activity of SCM extract might be stemmed from high total phenolic content or high rutin amount that is known with its high antioxidant capacity. 
Table 4: Antioxidant activity", total phenolic-flavonoid contents ${ }^{*}$ and anticholinesterase activity $(200 \mu \mathrm{g} / \mathrm{mL})^{*}$ of $S$. compacta extracts, BHT, $\alpha$-TOC and galantamine.

\begin{tabular}{|c|c|c|c|c|c|c|c|}
\hline Samples & $\begin{array}{l}\text { Inhibition \% } \\
\text { against AChE }\end{array}$ & $\begin{array}{l}\text { Inhibition \% } \\
\text { against BChE }\end{array}$ & $\begin{array}{l}\text { Phenolic content } \\
\quad(\mu \mathrm{g} \text { PEs/mg } \\
\text { extract })^{\alpha}\end{array}$ & $\begin{array}{l}\text { Flavonoid content } \\
\qquad \begin{array}{c}\mu \mathrm{g} \mathrm{QEs} / \mathrm{mg} \\
\text { extract })^{\beta}\end{array}\end{array}$ & $\begin{array}{c}\text { Lipid } \\
\text { Peroxidation }\end{array}$ & $\begin{array}{c}\mathrm{IC}_{50}(\mu \mathrm{g} / \mathrm{mL}) \\
\text { DPPH Free } \\
\text { Radical }\end{array}$ & $\begin{array}{c}\text { ABTS Cation } \\
\text { Radical }\end{array}$ \\
\hline SCP & $86.03 \pm 2.10^{\mathrm{a}}$ & $28.65 \pm 1.2^{\mathrm{a}}$ & $59.61 \pm 3.74^{\mathrm{a}}$ & $27.61 \pm 0.41^{\mathrm{a}}$ & $52.45 \pm 1.21^{\mathrm{a}}$ & $141.45 \pm 2.19^{a}$ & $118.18 \pm 2.19^{\mathrm{a}}$ \\
\hline SCA & $75.21 \pm 0.73^{\mathrm{b}}$ & $37.65 \pm 3.2^{\mathrm{b}}$ & $84.14 \pm 2.22^{\mathrm{b}}$ & $47.23 \pm 0.14^{\mathrm{b}}$ & $42.91 \pm 0.72^{\mathrm{b}}$ & $155.83 \pm 3.69^{\mathrm{b}}$ & $57.78 \pm 1.19^{\mathrm{b}}$ \\
\hline SCM & $93.75 \pm 1 .{ }^{2} 3 \mathrm{c}$ & $84.43 \pm 1.52 c$ & $108.94 \pm 2.68^{c}$ & $55.88 \pm 0.15 c$ & $26.37 \pm 0.88^{c}$ & $56.78 \pm 2.12^{c}$ & $16.91 \pm 0.66^{c}$ \\
\hline SCW & $65.47 \pm 0.57^{\mathrm{d}}$ & $55.12 \pm 2.44^{\mathrm{d}}$ & $72.56 \pm 0.06^{\mathrm{d}}$ & $47.16 \pm 0.09^{\mathrm{b}}$ & $41.94 \pm 1.12^{\mathrm{b}}$ & $128.98 \pm 1.91^{\mathrm{d}}$ & $55.45 \pm 2.18^{\mathrm{b}}$ \\
\hline Galantamine $^{\dagger}$ & $85.55 \pm 0.55^{\mathrm{a}}$ & $79.22 \pm 1.22^{\mathrm{e}}$ & - & - & - & - & - \\
\hline$\alpha-\mathrm{TOC}^{\dagger}$ & - & - & - & - & $11.45 \pm 0.45^{\mathrm{d}}$ & $19.09 \pm 0.11^{\mathrm{e}}$ & $9.92 \pm 0.17^{\mathrm{d}}$ \\
\hline $\mathrm{BHT}^{\dagger}$ & - & - & - & - & $8.41 \pm 0.31^{\mathrm{e}}$ & $48.64 \pm 0.06^{\mathrm{f}}$ & $10.90 \pm 0.16^{\mathrm{e}}$ \\
\hline
\end{tabular}

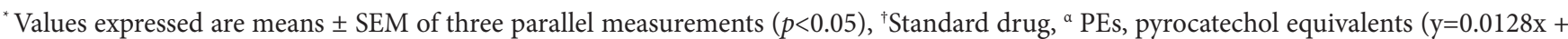
$\left.0.0324 \mathrm{R}^{2}=0.9924\right),{ }^{\beta} \mathrm{QEs}$, quercetin equivalents $\left(\mathrm{y}=0.1701 \mathrm{x}-0.0778 \mathrm{R}^{2}=0.9939\right)$.

\section{Cholinesterases inhibitory activities}

As shown in Table 4, the SCM extract exhibited strong cholinesterases inhibitory activities, and this extract indicated higher inhibitory effect against acetyl- and butyrylcholinesterase enzymes $(93.75 \pm 1.23$ and $84.43 \pm 1.52 \%$ inhibition, respectively) than the reference compound, galantamine, at $200 \mu \mathrm{g} / \mathrm{mL}$.

To the best of our knowledge, there is not any reports on the cholinesterases inhibitory activities of Silene species. Taking into account that our results were higher than galanthamine and there has been no such study on Silene species, the cholinesterases inhibitory activities results of $S$. compacta will be important data in this field.

\section{Cytotoxicity activity}

MTT assay was used to determine cell viability. Only the medium was applied for control group. Figure 2 shows viability of L929 fibroblast cells and Figure 3 cell viability of A549. In the control group there were no toxicity. Generally

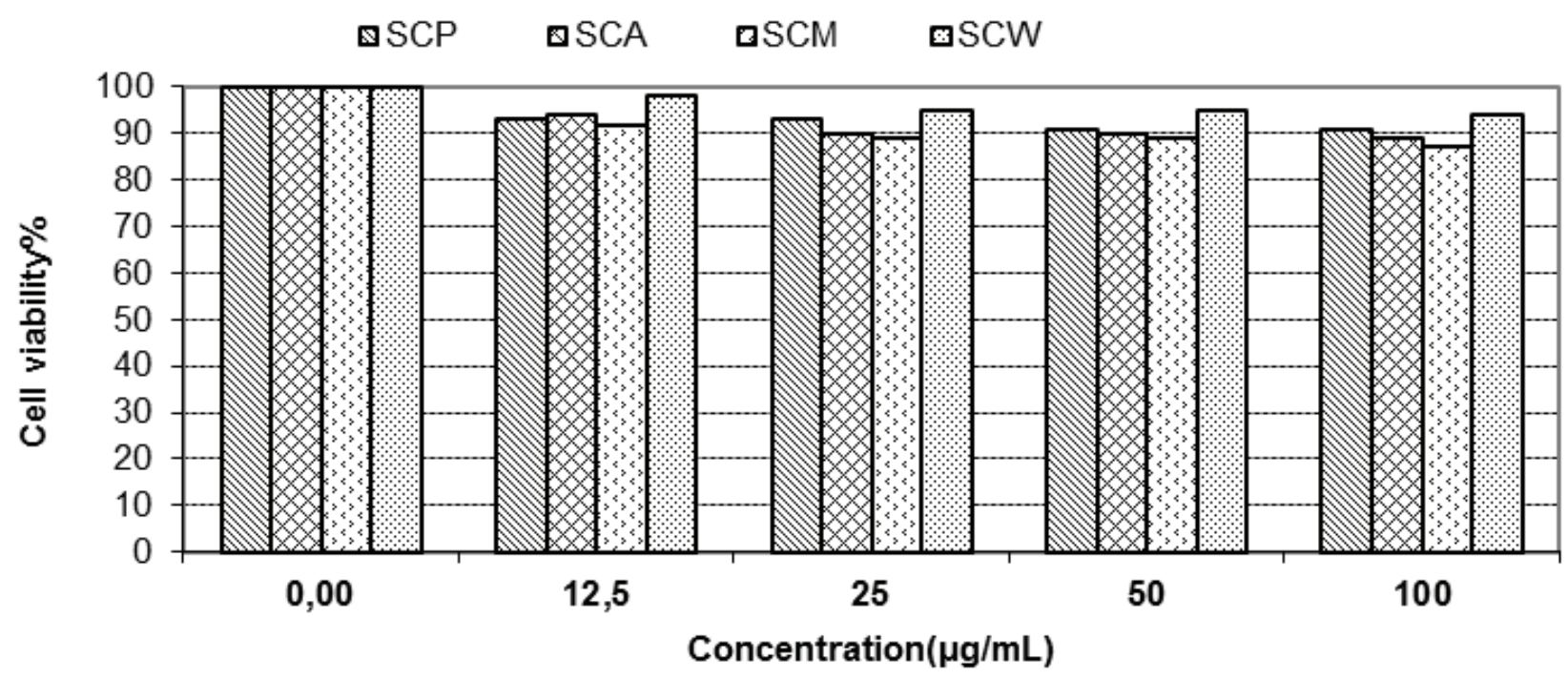

Figure 2. L929 Cytotoxic activity of S. compacta extracts. 


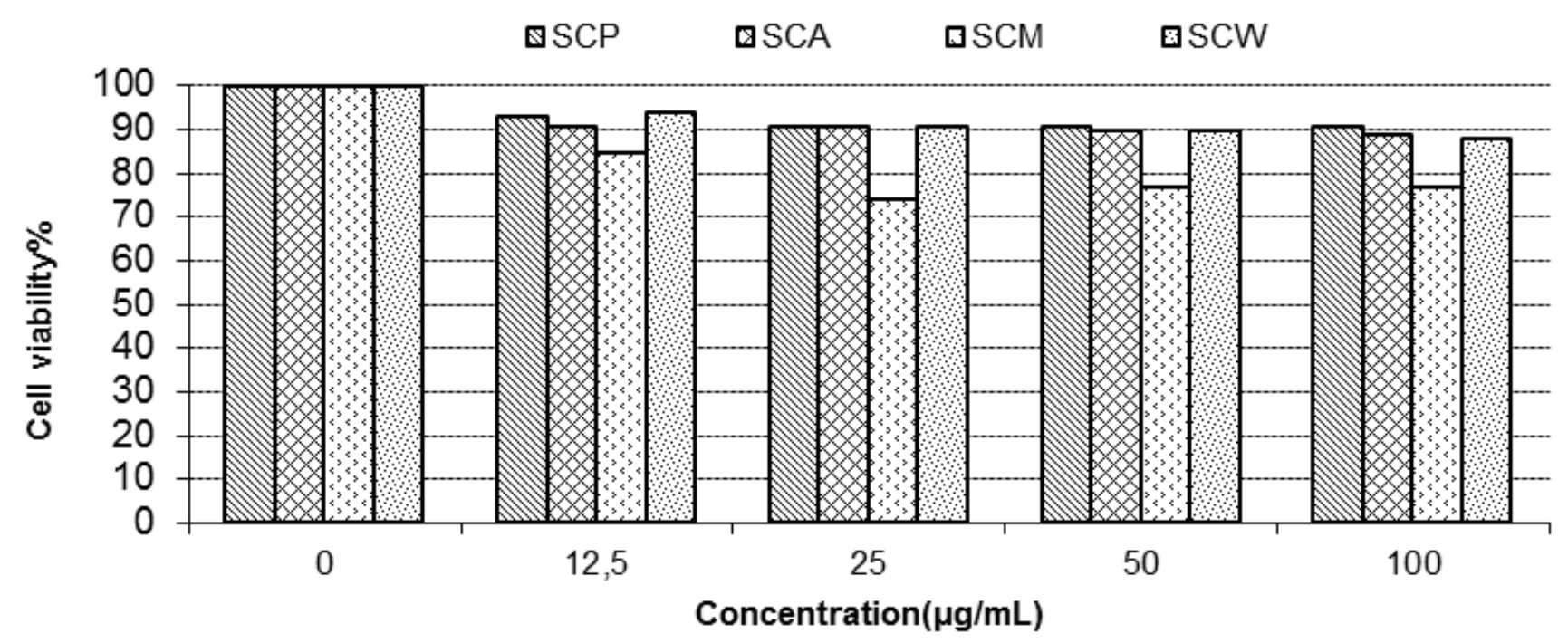

Figure 3. A549 Cytotoxic activity of S. compacta extracts.

at all concentration, the highest cytotoxic effect was found in SCM extract applied to A549 cells. The highest effect has shown by SCM extract at $25 \mu \mathrm{g} / \mathrm{mL}$ concentration $(74 \%$ viability). In addition, when SCM extract applied to L959 fibroblast cells in the same concentration $(25 \mu \mathrm{g} / \mathrm{mL}), \mathrm{SCM}$ extract has shown high nontoxic effect ( $89 \%$ viability).

It is concluded that the report represents the first study on chemical composition and biological activities of S. compacta. Silene species possess mainly triterpene saponins and ecdysteroids [4, 5]. Although there are a lot of studies in this area, there are few studies on their phenolic contents. Thus, the phenolic content of Silene compacta might be a valuable data in this field. While the methanol extract displayed a good level of antioxidant properties in four tested methods, the present study concluded that this extract showed very strong cholinesterases inhibitory activities. Further phytochemical and biological studies are needed to characterize the active constituents of $S$. compacta.
Silene compacta (Fischer) Ekstrelerinin Kimyasal İçerikleri, Sitotoksik, Antioksidan ve Kolinesteraz İnhibitor Aktiviteleri

\section{ÖZ}

Silene türleri Türkiye'de halk arasında mesane ve safra yolları infüzyonunda kullanılmaktadır.

Silene türleri Avrupa ve Anadolu'da yiyecek olarak tüketilmektedir. Bu çalışmada Silene compacta Fischer (SC) bitkisinin fenolik, yağ asidi ve uçucu yağ kompozisyonları ile sitotoksik, antioksidan ve antikolinesteraz aktiviteleri, toplam fenolik ve flavonoid içerikleri çalışılmıştır. Uçucu yağ ve yağ asidi bileşenleri GC-MS cihazı ile belirlendi. Metanol ekstresinin kimyasal bileşimi kalitatif ve kantitatif olarak LC-MS/MS cihazı ile belirlendi. Uçucu yağ ve yağ asidinin ana bileşenleri sırasıyla $\alpha$-selinen (\%12.4) ve palmitik asit (\%26.3) olarak belirlendi. Çalışılan dört antioksidan test yöntemlerinde aktif olan methanol ekstresi çok güçlü antikolinesteraz enzim inhibisyon aktivitesi göstermiştir. Aynı zamanda methanol ekstresinin A549 hücre serilerine karşı en yüksek sitotoksik etkiyi gösterdiği belirlenmiştir. Metanol ekstresinin LC-MS/MS analizi sonucuna göre ana bileşenleri hesperidin, rutin, kuinik asit ve malik asit olarak belirlenmiștir.

Anahtar kelimeler: Silene compacta, LC-MS/MS, Yă̆ asidi, uçucu yağ, antikolinesteraz, antioksidan, sitotoksisite. 


\section{REFERENCES}

1. Davis PH, Mill RR, Tan K. Silene L. In: Flora of Turkey and the East Aegean Islands, suppl. 10. Edinburgh Univ. Press, Edinburgh. 1988.

2. Baytop T. Therapy with Plants in Turkey (Past and Present). Publications of Istanbul University, Istanbul.1984.

3. Laghetti G, Perrino P. Utilization of Silene vulgaris (Moench.) Garcke in Italy. Econ Bot 1994; 48: 337-9.

4. Glensk M, Wray V, Nimtz M, Schoepke T. Silenosides A-C, triterpenoid saponins from Silene vulgaris. J Nat Prod, 1999; 62: 717-21.

5. Gaidi G, Miyamoto T, Laurens V, Dubois MAL. New acylated triterpene saponins from Silene fortunei that modulate lymphocyte proliferation. J Nat Prod, 2002; 65: 1568-72.

6. Zibareva L, Yeriomina VI, Munkhjargal N, Girault JP, Dinan L, Lafont R. The phytoecdysteroid profiles of 7 species of Silene (Caryophyllaceae). Arch Insect Biochem Physiol 2009; 72: $234-48$.

7. Gasiorowski K, Brokos B, Glensk M, Schöpke T. Immunomodulatory activity of the saponinrich fraction from roots of Silene vulgaris Garcke: initial study. Pharmazie 1999; 54: 864-6.

8. Mamadalieva NZ, Chenko NT, Yuldasheva NK, Egamberdieva DR, Zhanibekov A, Dzhukharova MK, Glushenkova AI. Fatty acid composition and antibacterial activity of $\mathrm{CHCl}_{3}$ extracts of three plants of the genus Silene. Chem Nat Comp 2010; 46; 95-6.

9. Kucukboyaci N, Ozçelik B, Adıguzel N, Goren AC. Fatty-acid compositions of Silene vulgaris and S. cserei subsp. aeoniopsis seeds and their antimicrobial activities. Chem Nat Compd 2010; 46: 88-91.

10. Vivek B, Savita S, Chul KS. Chemical composition and antifungal activity of essential oil and various extract of Silene armeria L. Bioresource Technol 2008; 99: 8903-8.

11. Howes MJR, Perry NSL, Houghton PJ. Plants with traditional uses and activities relevant to the management of Alzheimer's disease and other cognitive disorders. Phytother Res 2003; 17: 1-18.

12. Ertas A, Boga M, Yılmaz MA, Yesil Y, Hasimi N, Kaya MS, Temel H, Kolak U. Chemical compositions by using LC-MS/ MS and GC-MS and biological activities of Sedum sediforme (Jacq.) Pau. J Agr Food Chem 2014; 62: 4601-9.

13. Yamazaki E, Inagaki M, Kurita O, Inoue T. Antioxidant activity of Japanese pepper (Zanthoxylum piperitum) fruit. Food Chem 2007; 100: 171-7.
14. Ertas A, Boga M, Yllmaz MA, Yesil Y, Tel G, Temel H, Hasimi N, Gazioglu I, Ozturk M, Ugurlu P. A detailed study on the chemical and biological profiles of essential oil and methanol extract of Thymus nummularius (Anzer tea): Rosmarinic acid. Ind Crop Prod 2015; 67: 336-45.

15. Ertas A, Boga M, Kizil M, Ceken B, Goren AC, Hasimi N, Demirci S, Topcu G, Kolak U. Chemical profile and biological activities of Veronica thymoides subsp. pseudocinerea. Pharm Biol 53; 2015: 334-9.

16. Ertas A, Yilmaz MA, Firat M. Chemical profile by LC-MS/ MS, GC/MS and antioxidant activities of the essential oils and crude extracts of two Euphorbia species. Nat Prod Res 2015; 29: 529-34.

17. Slinkard K, Singleton VL. Total phenol analyses: Automation and comparison with manual methods. Am J Enol Viticult 1977; 28: 49-55.

18. Moreno MIN, Isla MI, Sampietro AR, Vattuone MA. Comparison of the free radical-scavenging activity of propolis from several regions of Argentina. J Ethnopharmacol 2000; 71: 109-14.

19. Miller HE. A simplified method for the evaluation of antioxidants. J Am Oil Chem Soc 1971; 48: 91.

20. Blois MS. Antioxidant determinations by the use of a stable free radical. Nature 1958; 181: 1199-1200.

21. Re R, Pellegrini N, Proteggente A, Pannala A, Yang M, RiceEvans C. Antioxidant activity applying an improved ABTS radical cation decolorization assay. Free Radical Bio Med 1999; 26: 1231-7.

22. Apak R, Guclu K, Ozyurek M, Karademir SE. Novel total antioxidant capacity index for dietary polyphenols and vitamins $\mathrm{C}$ and $\mathrm{E}$, using their cupric ion reducing capability in the presence of neocuproine: CUPRAC Method. J Agric Food Chem 2004; 52: 7970-81.

23. Ellman GL, Courtney KD, Andres V, Featherstone RM. A new and rapid colorimetric determination of acetylcholinesterase activity. Biochem Pharmacol 1961; 7: 88-95.

24. Guo N, Ding W, Wang Y, Hu Z, Wang Z, Wang Y. An LCMS/MS method for the determination of salidroside and its metabolite p-tyrosol in rat liver tissues. Pharm Biol 2014; 52: 637-45.

25. Gatto MA, Ippolito A, Linsalata V, Cascarano NA, Nigro F, Vanadia S, Di Venere D. Activity of extracts from wild edible herbs against postharvest fungal diseases of fruit and vegetables. Postharvest Biol Tec 2011; 61: 72-82. 